\title{
Observance of Citizens' Rights and Freedoms as an Element of Political System of Modern Russia (Based on Researches in Krasnoyarsk Krai in 2010-2015) Rationale and Study Approaches
}

\author{
Valentin G. Nemirovskiy* \\ Siberian Federal University \\ 79 Svobodny, Krasnoyarsk, 660041, Russia
}

Received 20.01.2015, received in revised form 14.02.2015, accepted 19.03.2015

\begin{abstract}
Observance of citizens' rights and freedoms is the most important element of the political system, implemented in modern Russia. At the same time it is a necessary condition for its further improvement. It is necessary to take into account the hierarchy of importance of certain rights and freedoms for citizens. It is hierarchy that is a reflection of the corresponding norms and values in their legal awareness. Studies conducted within the framework of anthroposociocultural approach, developed by N.I. Lapin, show significant changes that have taken place in the hierarchy [Lapin, 2009: 772-775]. It evidences of evolution of the political system in Russia, as well as its value-regulatory elements. Yearslong studies identified significant regional differences in ideas of the population about the importance of rights and freedoms for population, as well as serious specificity in assessing the degree of their violation and possibility of protection [Lapin, 2009: 776]. In this regard, analysis of dynamics of the mentioned indicators, taking into account political preferences of the population of the large Siberian region is highly relevant. Similar studies from the standpoint of sociocultural approach, according to the similar method were carried out in different regions of the country [Belyaeva, 2008; Plekhanov, 2014: 170-176; Modernization... 2012, etc.], culturological studies in Krasnoyarsk Krai has also demonstrated considerable heuristic potential [Koptseva, Zamaraeva, Sertakova, 2011: Koptseva, Il'beikina, 2012; Koptseva, 2012]. From our point of view, this issue can also be effectively analyzed from the standpoint of postnonclassical universum sociology [Nemirovsky, 1994: 23-29; Nemirovsky, 2001].
\end{abstract}

Keywords: political system, citizens' rights and freedoms, sociocultural approach, value-regulatory system of society, sociocultural portrait of the region.

The study is carried out on the basis of researches, done with financial support from RHSF, project № 13-03-00379a "Dynamics of Sociocultural Processes in East Siberian Region within the Context of Contemporary Modernization of Russia (Based on Materials of Sociological Researches in Krasnoyarsk Krai).

DOI: 10.17516/1997-1370-2015-8-8-1675-1682.

Research area: sociology.

(C) Siberian Federal University. All rights reserved

* Corresponding author E-mail address: valnemirov@mail.ru 


\section{Methods of Study}

The article is based on the results of studies conducted in 2010 - 2015 in Krasnoyarsk Krai, that were carried out according to representative regional sampling, in accordance with the Standard programme and methods "Sociocultural Portrait of the Region" CRSCC IF RAS (Lapin, 2009; 15-40). Opinion polls were carried out by the method of structured interview at the respondents' place of residence, according to stratified, multi-leveled, regionalized and quota sampling, represented according to sex, age and the level of education, random at the stage of respondents' selection. Representativeness of sampling is provided by keeping proportions between the population living in settlements of various types (metropolitan areas, medium-sized and small towns, and rural settlements), age and gender and educational structure of the adult population of Krasnoyarsk Krai.

1. In $2010, n=1,000$ respondents, the study was carried out with financial support from RHSF, project № 10-03-00001a "Features of Sociocultural Portrait of Krasnoyarsk Krai."

3. In 2012, $n=1,300$ respondents, the study was carried out with financial support from RHSF, project № 11-03-00250a "Features of Social Structure and Social Capital Formation in Krasnoyarsk Krai."

4. In $2014, n=1,000$ respondents, the study was carried out with financial support from RHSF, project № 13-03-00379a "Dynamics of Sociocultural Processes in East Siberian Region within the Context of Contemporary Modernization of Russia (Based on Materials of Sociological Researches in Krasnoyarsk Krai)."

5. In 2015, mass survey of the region population was conducted by the structured interview method, $\mathrm{n}=1568$ respondents with the use of the methods specially developed by the author. The study was carried out with financial support from RHSF, project № 13-03- 00379a "Dynamics of Sociocultural Processes in East Siberian region within the Context of Contemporary Modernization of Russia (Based on Materials of Sociological Researches in Krasnoyarsk Krai)."

\section{Study Results}

It is known that any political system is stable and viable if it takes into account the specificity of the country in which it is implemented: socio-cultural characteristics, including mentality of the population, national political traditions, etc.

Over the past few years opinion of the region population regarding how the political system best suits the Russian specificity has slightly changed. In 2012, one in three was focused on the Western-style democracy, one in five - on the authoritarian regime, $7 \%$ of the respondents preferred the Soviet type system, $6 \%$ - public self-government. Since the question was semiopen, $30 \%$ of the respondents wrote their own opinion which is different from the given options. According to the results of content analysis of their responses, the majority believes that "authoritarian democracy" or "democratic society, but not Western-style" is the most appropriate for Russia. It is important to note that, on the one hand, a number of responses indicate of denial of fascism and nationalism as a political foundation of the Russian state. On the other hand, none of the respondents mentioned religious state in the open question, as well as did not use the concept of "civil society" (Nemirovsky, 2013: 82).

Taking into account the results obtained earlier, in 2015 refined methodology was used for the study. According to the results of the survey, conducted by the structured interview method, in 2015 in Krasnoyarsk Krai three types of political systems were the most preferred ones (corresponding to the Russian specificity) for the region population (Table 1): 
Table 1. Answers to the question "What political system, in your opinion, corresponds to the Russian specificity?" (up to three variants of answer are possible)

\begin{tabular}{|c|c|}
\hline Variants of answer & $\%$ \\
\hline Western-style democracy & 44 \\
\hline The state that exists in Russia today & 55 \\
\hline The Soviet type system & 25 \\
\hline Public self-government & 11 \\
\hline Religious state & 2 \\
\hline Authoritarian regime & 8 \\
\hline Other (write your option ): & 1 \\
\hline
\end{tabular}

- The state that exists in Russia today $55 \%$ of the respondents.

- Western-style democracy $-44 \%$.

- The Soviet type system - $25 \%$.

As it can be seen, the new data are well corresponded with the results of studies conducted by us in 2012. At that in the mass consciousness of the respondents there is no concept of "civil society". But this fact does not diminish the importance of its implementation for functioning of the two most preferred political systems for the respondents: the one created in Russia today and Western-style democracy.

The most important condition for the development of civil society is strict observance of citizens' rights and freedoms. For five years, the importance of observance of all the rights and freedoms represented in question № 47 of the methods of Sociocultural portrait of the region in the Krasnoyarsk Krai has slightly increased. The average value of answers "very important" increased from $59 \%$ in 2010 to $62 \%$ in 2012 . The surveyed residents of the region among the most significant rights and freedoms for them mentioned education and training (84\% in 2010 and $85 \%$ in 2012 considered it very important), the right to private property $(80 \%$ and $82 \%$ respectively), the right to work (77 \% and $80 \%$ ), equality before the law (77\% and $79 \%$ ), the right to security and protection of an individual
(75\% and $76 \%$ ), and finally, the right to privacy of personal correspondence (65\% and $73 \%$ ) (Nemirovsky, Nemirovskaya, 2010:198-204; Nemirovsky, Nemirovskaya, 2012:178-188).

The most significant growth took place in relation to the importance of observation of religious freedoms and the freedom of conscience for the population of Krasnoyarsk Krai - from $34 \%$ in 2010 to $43 \%$ in 2012. A very illustrative indicator of the level of development of civil legal awareness among the region population is the fact that only $50 \%$ of the respondents consider observance of the freedom of speech as very important (though for two years the number of respondents increased by almost $10 \%$ ), $37 \%$ the right to emigration ( $34 \%$ in 2010), $20 \%$ - the freedom of associations, groups and unions (15\% in 2010). It should be particularly noted that just over half of the respondents $-54 \%$ (48 \% in 2010) consider people's right to their own language and culture as very important for them.

In addition to that, in 2014 there was a noticeable decrease in importance of observance of certain rights and freedoms for the respondents: the average percentage of people who chose the answer "very important" decreased from $62 \%$ in 2012 to $57 \%$ in 2014 (Nemirovsky, Nemirovskaya, 2014: 71-75, 199-201). From 2010 to 2014 there was a certain decrease in values of certain rights and freedoms for the respondents, which were 
considered as "very important" by many of them: equality before the law (respectively, from $77 \%$ to $70 \%$ ), the right to work ( $77 \%$ and $67 \%$ ), the right to private property $(80 \%$ and $73 \%$ ), the right to education and training ( $82 \%$ and $77 \%)$. On the contrary, evaluation of the rights and freedoms that had previously occupied the bottom places in the hierarchy increased: the freedom of associations, groups and unions $-15 \%$ and $24 \%$, religious freedoms and the freedom of conscience $-34 \%$ and $40 \%$, the freedom of speech $-44 \%$ and $55 \%$, people's right to their own language and culture $48 \%$ and $52 \%$. Valuation of importance of other rights and freedoms of citizens has not almost changed (Nemirovsky, Nemirovskaya, 2014: 7175, 199-201).

Nevertheless, not all of the citizens' rights and freedoms are observed in real life. Most frequently, residents of Krasnoyarsk Krai face violation of equality before the law (58\% in 2010 and $63 \%$ in 2012 did not face it), their right to work (64\% in 2010 and $68 \%$ in 2012 did not face violation of this right) and the right to security and protection of an individual (66\% and $68 \%$ respectively did not meet violation of this right). Regarding these rights, the largest proportion of the respondents who did not try to defend these rights is detected, which indicates of their lack of faith in ability to achieve justice in these issues. Alongside with that, among the residents of the region who fought for their right of equality before the law and the right to work, $7 \%$ and $6 \%$ (in $2012-$ $6 \%$ and $7 \%$ ) of the respondents respectively, were able to defend them. The same can be also said about protection of the right to security and protection of an individual of the surveyed residents of the region. Unfortunately, the amount of those who more often were failed to defend these violated rights + percentage of those who have never succeeded in defending them, exceeds the figures shown.
For most of the other rights and freedoms, according to the respondents, they also more often failed to defend the violated rights + have never succeeded in doing that. However, in the general proportion, the amount of such responses is low. As a rule, they succeeded in defending the right of private property and the right to education and training. Overall, about two-thirds of the respondents did not face violations listed in the questionnaire of the citizens' freedoms and rights. This may be indicative of the success of development of the social atmosphere of civil society and its structures and elements in Krasnoyarsk Krai. The data obtained in 2014 also bear evidence of this (Nemirovsky, Nemirovskaya, 2014: 204). In particular, the three least violated rights and freedoms were identified. Thus, $75 \%$ of the respondents (77\% in 2010) did not face violation of the right to emigrate, people's right to their own language and culture - $73 \%$ (74\% respectively) and the freedom of associations, groups and unions $-73 \%$ (70\%).

In 2010, the most violated citizens' rights and freedoms in Krasnoyarsk Krai were equality before the law, the right to work and the right to security and protection of an individual. In 2012, the right to security and protection of an individual surpassed the right to work in the rankings of violations of rights and freedoms, taking the second position (Nemirovsky, Nemirovskaya, 2012: 174).

Both in 2010 and in 2012, the least three violated human rights and freedoms, according to the survey, included the right to emigrate, the freedom of conscience and religious freedoms, and the right to one's own language and culture.

The index of intensity of the assertion of rights that characterizes the proportion of respondents who defended the violated rights/ freedoms, from all those who faced their violation (FV) was used. In 2010, residents of Krasnoyarsk krai defended the right to private 
property, the right to equality before the law and the right to education most intensely. In 2012 , the right to security and protection of an individual led in the ranking of protection intensity, the second place was occupied by the right to education and the third by the right to private property. Perhaps there are more developed social-legal and institutional mechanisms of protection to defend these particular rights and freedoms of citizens in the Krasnoyarsk krai. It is characteristic that both in 2010, and two years later, two-thirds of this list do not coincide with the given above list of the three most violated rights and freedoms of citizens. Thus, the right to work is one of the most violated rights of citizens in the krai (VR (violation rating) $=2$ in $2010, \mathrm{VR}=3$ in 2012). However, according to the intensity of protection in 2010 it was in the $5^{\text {th }}$ place in ranking (in 2012 - in the $6^{\text {th }}$ ), and according to the indicator of successfulness of protection only in the $7^{\text {th }}$ (in $2012-$ in the $9^{\text {th }}$ )! It is obvious that this is one of the sore spots in social wellbeing of the residents of Krasnoyarsk krai, and an important problem area on the way of formation and implementation of the sociocultural potential of the region's population.

According to successfulness of protection, in 2010 the leading positions in the ranking was occupied by the right to education, the right to private property, as well as freedom of conscience and religious liberty. In 2012 the right to emigrate, the freedom of conscience and religious freedom, and the right to personal property were most successfully defended by the respondents.

Over the two-year period the average value of violation of rights and freedoms (from $12 \%$ in 2010 to $15 \%$ in 2012) in general slightly increased, but, at that, intensity of protection decreased (from 0.64 to 0.62), although successfulness of advocacy for the rights and freedoms of the surveyed residents of the region increased significantly (from 0.43 to 0.54 ). In 2014, (Nemirovsky, Nemirovskaya, 2014: 206) violation of citizens' rights and freedoms increased significantly: up to $19 \%$, i.e. by 1.6 times compared to 2010. Violations of human rights to equality before the law continue to occupy the first place in the ranking of citizens' rights and freedoms. In 2014, they already reached $31 \%$ (constituted $25 \%$ in 2010), violation of the right to privacy of personal correspondence from $8 \%$ in 2010 increased to $13 \%$ in 2014 , the right to freedom of speech, from $16 \%$ to $22 \%$ respectively, etc.

Such an important indicator as the intensity of protection of rights and freedoms in Krasnoyarsk krai slightly increased: from 0.64 in 2010 to 0.67 in 2014. What is important, the success of their protection during this period increased more significantly: from 0.43 to 0.59 . At that, the right to security and protection of an individual -0.72 , the right to private property -0.69 , the right to work -0.64 , the freedom of conscience, religious freedoms -0.64 , the freedom of speech -0.64 were the most successfully protected in 2014 .

Resume. Thus, serious sore spots in the process of development of civil society in the krai are revealed, which are indicated by the increased violations of certain rights and freedoms in the region and difficulties in their protection. In 2014 the least successfully protected were the right to emigration -0.48 , equality before the law -0.48 , the right to privacy of personal correspondence, etc. -0.51 . However, in general, based on the given data, it is possible to talk about significant progress in development of civil society in Krasnoyarsk krai.

It should be noted that in the past five years we observed major changes in the political and legal, and regulatory consciousness of the population of the krai. They have ambiguous character, because on the one hand, those rights and freedoms that reflect the desire of the population to development 
of democracy and spirituality and to preservation of their socio-cultural identity are getting a greater role. On the other hand, some fundamental political and socio-economic rights and freedoms are gradually reducing their importance. These are important indicators of the changes that take place in the political system implemented in our country.

\section{References}

1. Belyaeva L.A., Korepanov G.S., Shafranov-Kutsev G.F., Lapin N.I. Tiumenskii region v sovremennoi faze sotsiokul'turnoi evoliutsii Rossii [Tyumen Region in the Modern Phase of SocioCultural Evolution of Russia] The World of Russia. 2008. Vol. 17. № 1. Pp. 50-88.

2. Modernizatsiia ekonomiki regiona: sotsiokul'turnye aspekty: monographiia [Modernization of Economy of the Region: Socio-Cultural Aspects: monograph]. A.A. Shaburova, K.A. Gulin, M.A. Lastochkina, T.S. Solov'eva. Vologda: ISEDT RAS, 2012. - 158 p.

3. Plekhanov E.A. Sotsiokul'turnyi portret naseleniia Vladimiskoi oblasti [Socio-Cultural Portrait of the Population of Vladimir Oblast]. Socio-Cultural and Natural-Resource Factors of Balance of the Russian Regions Modernization: Proceeding of the $10^{\text {th }}$ All-Russian Research and Practical Conference on the Programme "Socio-Cultural Evolution of Russia and Its Regions", Perm, 14-17 October 2014. Perm State National Research University. - Perm, 2014. - 459 p.

4. Koptseva N.P., Zamaraeva J.S., Sertakova E.A. Sociocultural Research of the Cultural Requirements of the Residents of the Krasnoyarsk City. Journal of Siberian Federal University. Humanities \& Social Sciences. № 4. -2011. Pp. 1577-1588.

5. Koptseva N.P., Il'beikina M.I. “Tsivilizatsionnaia napravlennost' naseleniia Ob”edinennogo Krasnoiarskogo kraia: zhiteli goroda Krasnoiarska v vozraste ot 15 do 60 let" ["Civilizational Focus of the Population of the United Krasnoyarsk Krai: Dwellers of Krasnoyarsk Aged from 15 up to 60"]. “Philosophy and Culture”. № 4. 2012. Pp. 105-116.

6. Koptseva N.P. Metodologicheskiye vozmozhnosti sotsial'noi (kul'turnoi) antropologii dlya sovremennykh kul'turnykh issledovaniy [Methodological Opportunities of Social (Cultural) Anthropology for the Modern Cultural Research] // Filosofiya i kul'tura [Philosophy and Culture]. 2012. № 10. Pp. 9 - 18.

7. Lapin N.I. Chapter 14. Zastoinye sphery funktsionirovaniia regional'nykh soobshchestv i vyrashchivaniia institutov ikh samorazvitiia [Stagnant Spheres of Regional Communities Functioning and Development of Institutes of Their Self-Development]. Regions in Russia: SocioCultural Portraits of Regions in All-Russian Context. Institute of Philosophy. Centre for the Study of

Social and Cultural Change. Coordinating Research Council of FBS SSD RAS Section "Problems of Socio-Cultural Evolution of Russia and its Regions". Composion and Editing: N.I. Lapin, L.A. Belyaeva. M., Academia, 2009. P. 40, 772 - 776.

8. Nemirovsky V.G. Sovremennaia sotsiologiia i rossiiskie kul'turnye traditsii [Modern Sociology and Russian Cultural Traditions]. Sociological Researches. 1994, № 3. Pp. 23-29.

9. Nemirovsky V.G. Universumnaia diagnostika rossiiskogo obshchestva [Universum Diagnostics of Russian Society]. Krasnoyarsk, 2001. 176 p.

10. Nemirovsky V.G., Nemirovskaya A.V. Sotsiokul'turnyi portret Krasnoiarskogo kraia [SocioCultural Portrait of Krasnoyarsk Krai]. Krasnoyarsk: RIC of SibLI, 2010. 263 p. 
11. Nemirovsky V.G., Nemirovskaya A.V. Dinamika sotsiocul'turnykh protsessov v Krasnoyarskom krae (na materialakh sotsiologicheskikh issledovanii v regione 2010-2012) [Dynamics of Socio-Cultural Processes in Krasnoyarsk Krai (Based on the Materials of Sociological Researches in the Region in 2010-2012)]: Monograph / V.G. Nemirovsky, A.V. Nemirovskaya. Krasnoyarsk: Siberian Federal University, 2012, 246 p.

12. Nemirovsky V.G., Nemirovskaya A.V. Sotsioculturnaia modernizatsiia regionov Sibiri [SocioCultural Modernization of the Siberian Regions]: Monograph. Saint-Petersburg, "Petropolis", 2013, Pp. 14-16.

13. Nemirovsky V.G. Perekhod ot antiutopii k utopii v kontekste modernizatsionnykh protsessov v Rossii (na materialakh sotsiologicheskikh issledovanii v Krasnoiarskom krae) [Transition from AntiUtopia to Utopia in the Context of Modernization Processes in Russia (Based on the Materials of Sociological Researches in Krasnoyarsk Krai)] / Sociology: Methodology, Methods, Marketing. 2013, №3. Pp. 73-85.

14. Nemirovsky V.G., Nemirovskaya A.V. Sotsiokul'turnye protsessy v sibirskom regione (Krasnoyarskii Krai v 2010-2014 gg.) [Socio-Cultural Processes in Siberian Region (Krasnoyarsk Krai in 2010-2014)]: Monograph. Krasnoyarsk: Siberian Federal University, 2014. 244 p. 


\title{
Соблюдение прав и свобод граждан
}

как элемент политической системы современной России (по исследованиям в Красноярском крае в 2010-2015 гг.)

\author{
В.Г. Немировский \\ Сибирский федеральный университет \\ Россия, 660041, Красноярск, пр.Свободный, 79
}

Соблюдение прав и свобод граждан выступает важнейтим элементом политической системы, реализованной в современной России. Одновременно это необходимое условие её дальнейшего совершенствования. Необходимо учитывать иерархию значимости тех или иных прав и свобод для граждан. Именно она является отражением соответствующих норм и иенностей в их правосознании. Исследования, проводимые в рамках антропосоциокультурного подхода, разработанного Н.И. Лапиным, показывают существенные изменения, произошедшие в данной иерархии (Лапин, 2009: 772-775). Это свидетельствует об эволюции политической системы в России, а также её ценностнонормативных элементов. Многолетними исследованиями выявлены значительные региональные различия в представлениях населения о важности реализации прав и свобод граждан для населения, а также серьёзная специфика в оценках степени их нарушаемости и возможности защчиты (Лапин, 2009: 776). В этой связи весьма актуален анализ динамики отмеченных показателей с учётом политических предпочтений населения крупного сибирского региона. Аналогичные исследования с позиций соичокультурного подхода по сопоставимой методике проводились в различных регионах страны (Беляева, 2008; Плеханов, 2014: 170-176; Модернизачия... 2012 и др.), немалые эвристические возможности показали и культурологические исследования в Красноярском крае (Koptseva, Zamaraeva, Sertakova, 2011: Копцеева, Ильбейкина, 2012; Koptseva, 2012). На наш взгляд, данный вопрос может быть эффективно проанализирован также с позиций постнеклассической универсумной сочиологии (Немировский, 1994: 23-29; Немировский, 2001).

Ключевые слова: политическая система, права и свободы граждан, соичикультурный подход, иенностно-нормативная система общества, сощиокультурный портрет региона.

Работа выполнена на основе исследований, проведённых при финансовой поддержке РГНФ, проект № 13-03-00379а «Динамика сочиокультурных процессов в Восточно-Сибирском регионе в контексте современной модернизации России (на материалах социологических исследований в Красноярском крае)».

Научная специальность: 22.00.00 - социологические науки. 